\title{
Pengaruh Biaya Produksi, Pengalaman, Dan Keterampilan Terhadap Pendapatan Usahatani Kakao (Theobroma cacao) Di Kecamatan Karang Baru Kabupaten Aceh Tamiang
}

\author{
Cut Gustiana ${ }^{1} /$ Irwanto $^{2}$ \\ ${ }^{1}$ Dosen Tetap Prodi Agribinis \\ ${ }^{2}$ Alumni Prodi Agribinisnis \\ Fakultas Pertanian Universitas Samudra
}

RINGKASAN

Tujuan penelitian adalah untuk mengetahui pengaruh biaya produksi, pengalaman, dan keterampilan terhadap pendapatan usahatani kakao (Theobroma cacao) di Kecamatan Karang Baru Kabupaten Aceh Tamiang. Penelitian ini dilaksanakan di Kecamatan Karang Baru Kabupaten Aceh Tamiang Provinsi Aceh. Objek penelitian ini adalah petani yang memiliki usahatani kakao di Kecamatan Karang Baru Kabupaten Aceh Tamiang. Ruang lingkup penelitian ini terbatas pada biaya produksi, pengalaman, dan keterampilan terhadap pendapatan usahatani kakao di Kecamatan Karang Baru Kabupaten Aceh Tamiang,

Hasil penelitian rata-rata umur petani sampel di desa sampel adalah 42 tahun, pendidikan 8 tahun, pengalaman sebesar 16 tahun dan jumlah tanggungan keluarga sebanyak 5 orang. Rata-rata jumlah penggunaan biaya produksi usahatani kakao di Kecamatan Karang Baru sebesar Rp 611.460 per usahatani dan Rp 462.080 per hektar. Rata-rata jumlah pendapatan usahatani petani kakao di Kecamatan Karang Baru yaitu Rp. 37.937.349 per usahatani dan Rp 28.534.255 per hektar. Rata-rata tingkat keterampilan usahatani petani kakao di Kecamatan Karang Baru sebesar 2,6 skor. Hasil analisis regresi linear berganda diperoleh persamaan yaitu sebagai berikut: $\mathrm{Y}=5,01-0,45 \mathrm{X}_{1}+0,06 \mathrm{X}_{2}+0,10 \mathrm{X}_{3}$. Dari koefisien determinasi menunjukkan bahwa besar koefisien determinasi $\left(\mathrm{R}^{2}\right)$ dihasilkan nilai $\mathrm{R}^{2}=0,53$ atau $53 \%$. Ini berarti pendapatan petani dalam berusahatani kakao (Y) dipengaruhi oleh biaya produksi $\left(\mathrm{X}_{1}\right)$, pengalaman (X2), dan keterampilan (X3) sebesar 53\% dan sisanya sebesar $47 \%$ lagi dipengaruhi oleh faktor-faktor lain diluar variabel penelitian ini.

Hasil pengujian secara serempak diperoleh bahwa secara serempak variabel tingkat biaya produksi, pengalaman, dan keterampilan memberi pengaruh yang sangat nyata terhadap pendapatan petani dalam berusahatani kakao. Hasil pengujian secara parsial pada variabel biaya produksi $\left(\mathrm{X}_{1}\right)$, variabel pengalaman $\left(\mathrm{X}_{2}\right)$ dan variabel keterampilan $\left(\mathrm{X}_{3}\right)$ tidak berpengaruh nyata terhadap pendapatan usahatani kakao.

Kata Kunci: Kakao, produksi, pengalaman, keterampilan, pendapatan

\section{PENDA}

\section{HULUA}

$\mathbf{N}$

\section{Latar Belakang}

Kakao merupakan salah satu komoditas unggulan nasional setelah tanaman karet, kelapa sawit, kopi, dan teh. Kakao merupakan salah satu komoditas perkebunan yang berperan penting bagi pertumbuhan perekonomian Indonesia terutama dalam penyediaan lapangan kerja baru, sumber pendapatan petani dan penghasil devisa bagi negara.

Budidaya tanaman kakao di Indonesia sampai dengan tahun 2006 diperkirakan mencapai luasan 1,2 juta ha tersebar di 32 propinsi dengan produksi sekitar 780 ribu ton biji kakao kering. Perkebunan rakyat meliputi sekitar $92 \%( \pm 1,1$ juta ha) dari total luasan dan menyumbang $93 \%$ ( \pm 723 ribu ton) dari total produksi dan melibatkan sekitar 1,16 juta keluarga tani (Rahmat, 2008:17). Ditinjau dari berbagai aspek, Kabupaten Aceh Tamiang sangat potensial untuk pengembangan tanaman kakao, baik ditinjau dari segi keadaan tanah, iklim, luas lahan dan penyediaan tenaga kerja maupun keadaan sosial ekonomi pertanian di daerah tersebut.

Produksi merupakan kegiatan yang menghasilkan barang baik barang jadi maupun barang setengah jadi, bahan industri dan suku cadang atau spareparts dan komponen. Hasil produksinya dapat berupa barang-barang konsumsi maupun barang- barang industri. 
Produksi adalah kegiatan untuk menciptakan atau menambah kegunaan suatu barang atau jasa. Dalam proses produksi terdapat biaya yang harus dikeluarkan untuk memperoleh hasil yang maksimal.

Usahatani merupakan suatu tempat dimana seseorang atau sekumpulan orang berusaha mengelola unsur-unsur produksi seperti alam, tenaga kerja, modal dan keterampilan dengan tujuan berproduksi untuk menghasilkan sesuatu di lapangan pertanian. Pengelolaan usahatani berhubungan dengan kegiatan orang melakukan pertanian dan permasalahan yang ditinjau secara khusus dari kedudukan pengusahanya sendiri atau Ilmu usahatani yaitu menyelidiki cara-cara seorang petani sebagai pengusaha dalam menyusun, mengatur dan menjalankan perusahaan itu.

Karakteristik petani merupakan keadaan atau kondisi petani yang menyelenggarakan dan mengelola usahatani. Karakteristik petani akan mempangaruhi peningkatan produksi dan pendapatan usahatani. Karakteristik merupakan bentuk minat dan motivasi petani dalam berusahatani, karena dengan adanya minat dan motivasi petani akan lebih giat dalam meningkatkan produksi usahataninya diantaranya adalah pengalaman dan keterampilan.

Keterampilan merupakan salah satu tehnik atau keahlian pengelolaan dalam usahatani, dengan mengimplementasikan berbagai komponen teknologi budidaya yang memberikan efek sinergis. Dengan keterampilan yang dimiliki diharapkan mampu meningkatkan produktivitas dan efisiensi usahatani yang selanjutnya memberi dampak terhadap peningkatan pendapatan dan kesejahteraan petani.

Pengalaman merupakan hal yang tidak dapat dipisahkan dari kehidupan manusia sehari-harinya. Pengalaman juga sangat berharga bagi setiap manusia, dan

\section{Hipotesis}

Biaya produksi, pengalaman, dan keterampilan berpengaruh terhadap pendapatan usahatani kakao (Theobroma cacao) di Kecamatan Karang Baru Kabupaten Aceh Tamiang. pengalaman juga dapat diberikan kepada siapa saja untuk digunakan dan menjadi pedoman serta pembelajaran manusia.

Pengalaman petani juga sangat membantu dan menunjang kemampuan untuk mengadopsi teknologi dalam usahataninya. Sebagai asumsi bahwa semakin tinggi tingkat pengalaman yang didapatkan maka pola pikir petani juga akan semakin luas. Sehingga rendahnya tingkat pengalaman seorang petani merupakan salah satu faktor penghambat dalam pengembangan sektor pertanian. Dengan tingginya tingkat pengalaman petani juga dapat mendukung dalam upaya pengelolaan lahan pertanian yang tidak merusak ekosistem di sekitarnya.

Berdasarkan uraian tentang biaya produksi yang meliputi pembelian bibit, pupuk, dan obat-obatan serta karakteristik petani, untuk menentukan dalam usahatani terhadap pendapatan yaitu yang meliputi pengalaman dan keterampilan yang memberikan kontribusi pengetahuan, keahlian dan tingkat kemampuan yang tinggi dalam melaksanakan kegiatan usahatani. Berdasarkan uraian tersebut maka penulis ingin mengetahui pengaruh penggunaan biaya produksi terhadap pendapatan usahatani kakao di Kecamatan Karang Baru Kabupaten Aceh Tamiang.

\section{Identifikasi Masalah}

Apakah biaya produksi, pengalaman, dan keterampilan berpengaruh terhadap pendapatan usahatani kakao (Theobroma cacao) di Kecamatan Karang Baru Kabupaten Aceh Tamiang.

\section{Tujuan Penelitian}

Untuk mengetahui pengaruh biaya produksi, pengalaman, dan keterampilan terhadap pendapatan usahatani kakao (Theobroma cacao) di Kecamatan Karang Baru Kabupaten Aceh Tamiang.

\section{METODE PENELITIAN \\ Lokasi, Objek, Ruang Lingkup dan Waktu Penelitian}

Penelitian ini dilakukan di Kecamatan Karang Baru Kabupaten Aceh Tamiang Provinsi Aceh dengan pertimbangan bahwa Kecamatan Karang Baru merupakan 
salah satu daerah yang terdapat usahatani kakao. Penelitian ini menggunakan "metode survey". Metode survey adalah metode dimana hanya sebagian dari populasi saja yang diambil dan digunakan untuk menentukan sifat serta ciri yang dikehendaki dari populasi (Nazir 2005:271).

Objek penelitian ini adalah petani yang menanam tanaman kakao di Kecamatan Karang Baru Kabupaten Aceh Tamiang. Ruang lingkup penelitian ini terbatas pada pengaruh penggunaan biaya produksi, pengalaman, keterampilan dan pendapatan usahatani kakao di Kecamatan Karang Baru Kabupaten Aceh Tamiang.

\section{Populasi dan Sampel Penelitian}

Populasi dalam penelitian ini adalah semua petani kakao yang terdapat di Kecamatan Karang Baru Kabupaten Aceh
Tamiang. Kecamatan Karang Baru terdiri dari 31 desa diambil 3 sebagai desa sampel yaitu desa Dalam, desa Suka Jadi Paya Bujok, dan desa Paya Awe dengan cara "Purposive Sampling". Dengan pertimbangan bahwa desa sampel tersebut memiliki usahatani kakao yang lebih luas dibandingkan desa-desa lain yang ada di Kecamatan Karang Baru Kabupaten Aceh Tamiang. Menurut Sugiyono (2008:122) "Purposive Sampling" adalah teknik penentuan sampel dengan pertimbangan tertentu. Dari jumlah populasi petani masing-masing desa sampel diambil 30\% sebagai petani sampel. Menurut Arikunto (2006:112), jika populasinya besar atau lebih dari 100 maka dapat diambil $10-15 \%$ atau 20-25\% atau lebih. Jumlah populasi dan petani sampel masing-masing desa adalah seperti terlihat pada tabel berikut ini:

Tabel III-1. Jumlah Populasi dan Petani Sampel Usahatani Kakao di Kecamatan Karang Baru, 2015.

\begin{tabular}{|c|l|c|c|}
\hline No & \multicolumn{1}{|c|}{ Desa } & Populasi (Orang) & Sampel (Orang) \\
\hline 1 & Dalam & 37 & 11 \\
2 & Suka Jadi Paya Bujok & 45 & 14 \\
3 & Paya Awe & 34 & 10 \\
\hline & Jumlah & 116 & 35 \\
\hline
\end{tabular}

Sumber : Data Primer (Diolah), 2015

Pada tabel di atas dapat dilihat bahwa petani sampel dari jumlah masing- masing populasi itu dengan mengambil $30 \%$ dari tiap-tiap populasi desa sampel sehingga total sampel berjumlah 35 orang yang terdiri dari Desa Dalam sebanyak 11 orang, Desa Suka Jadi Paya Bujok sebanyak 14 orang, dan Desa Paya Awe sebanyak10 orang, sehingga total petani sampel adalah 35 orang.

\section{Variabel dan Data yang Dianalisis}

Sesuai dengan latar belakang, kerangka pemikiran dan hipotesis yang telah diformulasikan maka dibutuhkan variabel sebagai berikut :
a. Luas Lahan (Ha)
b. Tenaga Kerja (HKP/Ha/Tahun)
c. Biaya Produksi :
- $\quad$ Bibit (Rp/Ha/Tahun)
- Pupuk (Rp/Ha/Tahun)
- Pestisida (Rp/Ha/Tahun)

d. Produksi (Kg/Ha/Tahun)

e. Harga $(\mathrm{Rp} / \mathrm{Kg})$

f. Nilai Produksi (Rp/Ha/Tahun) g. Pendapatan ( $\mathrm{Rp} / \mathrm{Ha} / \mathrm{Tahun})$

h. Tingkat Keterampilan (Skor)

i. Pengalaman (Tahun)

\section{Metode Analisis dan Pengujian Hipotesis Analisis Data}

Data yang diperoleh dari lapangan baik data primer maupun data sekunder diolah dengan mentabulasikan dan kemudian dipindahkan ke dalam bentuk tabelaris sesuai dengan kebutuhan analisis.

Total penerimaan (pendapatan kotor) adalah total penerimaan dari hasil penjualan kakao. Total penerimaan diperoleh dengan menggunakan rumus sebagai berikut :

Total Penerimaan= Jumlah produksi $\mathrm{x}$ Harga Per satuan

$$
\begin{aligned}
& \text { TR }=(\mathrm{Y}) \times \quad(\mathrm{Py}) \ldots \ldots \ldots \ldots \text { (Rahim, } \\
& \text { 2007:66) } \\
& \text { Keterangan : } \\
& \text { TR = Total Penerimaan } \\
& \mathrm{Y} \quad=\text { Produksi Kakao } \\
& \text { Py = Harga Kakao } \\
& \quad \text { Pendapatan bersih adalah besarnya }
\end{aligned}
$$


total penerimaan dari hasil penjualan kakao setelah dikurangi total biaya produksi yang dikeluarkan. Pendapatan bersih diperoleh dengan rumus :

$$
\begin{aligned}
& \mathrm{Pd}=\text { TR }- \text { TC........ } \\
& 2002: \text { 58) Keterangan : } \\
& \mathrm{Pd}=\text { Pendapatan Bersih } \\
& \text { TR = Total Penerimaan } \\
& \text { TC }=\text { Total Biaya }
\end{aligned}
$$

(Soekartawi,

\section{Pengujian Hipotesis}

$$
\begin{aligned}
& \text { Model yang digunakan dalam } \\
& \hat{Y}=a_{0}+a_{1} X_{1}+a_{2} X_{2}+a_{3} X_{3}+\text { e....(Sudjana, 2005:347) } \\
& \text { Keterangan : } \\
& \hat{\mathrm{Y}}=\text { Pendapatan }(\mathrm{Rp} / \mathrm{Ha} / \mathrm{Tahun}) \\
& \mathrm{X}_{1} \quad=\text { Biaya Produksi }(\mathrm{Rp} / \mathrm{Ha} / \mathrm{Tahun}) \\
& \mathrm{X}_{2} \quad=\text { Pengalaman (Tahun) } \\
& \mathrm{X}_{3}=\text { Keterampilan (Skor) } \\
& \mathrm{a} 0 \quad=\text { Konstanta } \\
& \text { a1, a2 dan a3 = Koefisien Regerasi yang dicari } \\
& \text { e } \\
& =\text { Error (galat) }
\end{aligned}
$$

Untuk melihat perbandingan antara $\mathrm{Y}$ yang dijelaskan oleh variabel $\mathrm{X}_{1}, \mathrm{X}_{2}$ dan $\mathrm{X}_{3}$ digunakan koefisiensi determinasi. Sudjana, (2005:383) menjelaskan "Koefisiensi determinasi $\left(\mathrm{R}^{2}\right)$ adalah proporsi keragaman atau variansi total nilai peubah Y yang dapat dijelaskan oleh nilai peubah X melalui hubungan linier".

Untuk menguji pengaruh secara serempak variabel Independen $\left(\mathrm{X}_{1}, \mathrm{X}_{2}\right.$ dan $\mathrm{X}_{3}$ ) terhadap variabel dependen (Y), digunakan Uji F. Sudjana (2005:385) menjelaskan "Uji $\mathrm{F}$ adalah metode pengujian yang dilakukan untuk mengetahui pengaruh variabel bebas secara bersama-sama terhadap variabel terikat".

Dengan kaidah keputusan :

F hit. $>\mathrm{F}$ tabel, pada taraf $0,05=95 \%$ dan $0,01=99 \%$, terima Ha dan tolak Ho

F hit. < F tabel, pada taraf $0,05=95 \%$ dan $0,01=99 \%$, tolak Ha dan terima Ho

Kriteria penerimaan atau penolakan hipotesis :

$$
\begin{array}{rlr}
\mathrm{Ha}= & \multicolumn{1}{c}{\text { Faktor }} & \text { produksi, } \\
\text { pengalaman, } & \text { dan } \\
\text { keterampilan } & \text { secara } \\
\text { serempak } & \text { berpengaruh } \\
\text { terhadap pendapatan usahatani }
\end{array}
$$

\section{HASIL DAN PEMBAHASAN}

\section{Karakteristik Petani}

Karakteristik merupakan gambaran atau keadaan individu. Karakteristik yang dimaksud dalam penelitian ini adalah AGRISAMUDRA, Jurnal Penelitian Vol. 4 No.2 Julii - Desember 2017 peneltian ini adalah dengan menggunakan regresi Linier Berganda dengan 3 (tiga) variabel bebas dan 1 (satu) variabel terikat. Menurut Sudjana (2005:347) Menjelaskan "Regresi Linier Berganda adalah untuk mengetahui arah hubungan antara variabel independen $(\mathrm{X})$ dengan variabel dependen (Y) behubungan positif atau negatif dan untuk memprediksi nilai dari variabel dependen apabila nilai variabel independen mengalami kenaikan atau penurunan". Persamaan adalah sebagai berikut :

$$
\begin{aligned}
& \text { kakao Di Kecamatan Karang } \\
& \text { Baru Kabupaten Aceh } \\
& \text { Tamiang. } \\
& \text { Ho = Faktor produksi, } \\
& \begin{array}{lr}
\text { pengalaman, } & \text { dan } \\
\text { keterampilan } & \text { secara }
\end{array} \\
& \text { serempak tidak berpengaruh } \\
& \text { terhadap pendapatan usahatani } \\
& \text { kakao Di Kecamatan Karang } \\
& \text { Baru Kabupaten Aceh } \\
& \text { Tamiang. }
\end{aligned}
$$

Untuk mengetahui pengaruh masingmasing variabel atau secara parsial digunakan Uji t untuk pengujian. Sudjana, (2005:373) menjelaskan "Uji $\mathrm{t}$ adalah metode pengujian yang dilakukan untuk mengetahui pengaruh variabel bebas secara individual terhadap variabel terikat".

Dengan ketentuan pengambilan keputusan:

Jika thit > tabel, pada taraf

$0,05=95 \%$ dan $0,01=99 \%$,

maka terima Ha tolak Ho Jika

thit $<$ tabel, pada taraf $0,05=$

$95 \%$ dan $0,01=99 \%$, maka

tolak Ha terima $\mathrm{Ho}$ karakteristik petani yang meliputi umur, pendidikan, pengalaman, dan jumlah tanggungan. Keadaan karakteristik ini dapat mempengaruhi kegiatan dan kemampuan kerja 
petani dalam berusahatani. Dalam menjalankan usahataninya, tiap petani memegang dua peranan yaitu petani sebagai juru tani (cultifator) dan sekaligus seorang pengelola (manager). Peranan petani dalam usahatani mencakup semua aspek sehingga menghendaki adanya keahlian dan keterampilan yang tergantung pada beberapa faktor, diantaranya umur, pendidikan, pengalaman dan jumlah tanggungan keluarga petani yang berusahatani kakao. Rata-rata umur petani sampel usahatani kakao di Kecamatan Karang Baru adalah 42 tahun, berdasarkan rata-rata umur usahatani kakao petani sampel menunjukkan bahwa umur tersebut masih produktif dalam berusahatani. Faturochman, (2004:2) menjelaskan Makin tinggi tingkat umur, maka pengalaman bertambah, sehingga makin tinggi umur maka tingkat keterampilan dan kemampuan dalam mengelola usahatani makin tinggi.Selain umur, pendidikan petani sampel yang berusahatani kakao rata-rata 8 tahun. Ini berarti pendidikan usahatani kakao di Kecamatan Karang Baru rata-rata tamatan Sekolah Dasar (SD). Sedarmayanti (2003:3), menambahkan bahwa tingkat pendidikan mempengaruhi daya fikir seseorang dalam menentukan keputusan terhadap inovasiinovasi yang didapat. Rata-rata pengalaman petani sampel dalam usahatani kakao sebesar 16 tahun. Seseorang yang mempunyai tingkat pengalaman yang tinggi akan menghasilkan kerja yang lebih baik. Disamping itu dari pengalaman akan mencerminkan keahlian yang dimiliki oleh seorang tenaga kerja karena pengalaman berhubungan ke arah keahlian dan keterampilan (Simamora, 1995:3).Rata-rata jumlah tanggungan keluarga sebanyak 5 orang. Banyaknya jumlah tanggungan keluarga berpengaruh terhadap pola produksi dan konsumsi petani serta mengakibatkan perbedaan produksi dan pendapatan. Semakin banyak tenaga kerja semakin tinggi pula biaya yang dikeluarkan untuk konsumsi sehingga semakin kecil dana yang dapat dialokasikan untuk biaya usahatani, tetapi di sisi lain semakin banyak anggota keluarga yang aktif berusahatani berpeluang memperoleh pendapatan yang lebih tinggi (Pratiwi, 2009:15)

\section{Luas Lahan}

Luas lahan garapan dalam penelitian ini adalah luas tanah yang digunakan untuk kegiatan usahatani, dimana luas lahan garapan sangat menentukan besar kecilnya produksi yang dihasilkan. Luas lahan garapan yang diusahakan petani berbeda antara petani satu dengan petani yang lainnya. Untuk lebih jelas mengenai luas lahan garapan usahatani kakao di daerah penelitian dapat dilihat pada tabel IV-2 berikut:

Tabel IV-2. Rata-rata Luas Lahan Usahatani Kakao di Kecamatan Karang Baru, 2016.

\begin{tabular}{|c|l|c|}
\hline No & \multicolumn{1}{|c|}{ Desa } & Luas Lahan (Ha) \\
\hline 1 & Dalam & 1,45 \\
2 & Suka Jadi Paya Bujok & 1,18 \\
3 & Paya Awe & 1,35 \\
\hline & Jumlah & 3,98 \\
\hline & Rata-rata & 1,33 \\
\hline
\end{tabular}

Sumber : Data primer diolah, 2016

Dari tabel IV-2 diatas dapat dilihat bahwa rata-rata luas lahan usahatani di daerah penelitian adalah 1,33 hektar dengan rincian di Desa Dalam yaitu 1,45 hektar, Desa Suka Jadi Paya Bujok yaitu 1,18 hektar, dan Desa Paya Awe yaitu 1,35 hektar. Lahan yang diusahakan dalam suatu kegiatan usahatani dapat mempengaruhi tinggi rendahnya pendapatan yang diperoleh petani. Semakin luas lahan usahatani yang dikelola oleh petani maka akan semakin besar peluang petani untuk memperoleh produksi yang tinggi, sekaligus dapat meningkatkan pendapatan usahataninya. Produktivitas usahatani semakin luas pemilikan lahan maka petani atau produsen dapat mengalokasikan faktor produksi berdasarkan prinsip efisiensi teknis dan efisiensi harga (Shinta, 2011:35).

\section{Penggunaan Tenaga Kerja}

Tenaga kerja merupakan salah satu 
faktor penting dalam menjalankan kegiatan produksi. Penggunaan tenaga kerja yang efisien dan efektif dapat mempengaruhi pengeluaran biaya produksi dalam menjalankan usahataninya. Jenis kegiatan tenaga kerja dalam penelitian ini meliputi penanaman, pemupukan, pemeliharaan, pemanenan dan pasca panen. Untuk lebih jelas tentang penggunaan tenaga kerja berdasarkan jenis kegiatan dapat dilihat pada tabel berikut ini:

Tabel V-3. Rata-rata Penggunaan Tenaga Kerja Usahatani Kakao Berdasarkan Jenis Kegiatan di Kecamatan Karang Baru, 2016.

\begin{tabular}{|c|l|r|r|r|r|}
\hline \multirow{2}{*}{ No Jenis Kegiatan } & \multicolumn{2}{|c|}{ TK (HKP) } & \multicolumn{2}{c|}{ Total (HKP) } \\
\cline { 3 - 6 } & & Per UT & Per Ha & Per UT & \multicolumn{1}{c|}{ Per Ha } \\
\hline 1 & Penanaman & 9,53 & 7,19 & 9,53 & 7,19 \\
2 & Pemupukan & 16,40 & 12,43 & 16,40 & 12,43 \\
3 & Pemeliharaan & 10,45 & 8,02 & 10,45 & 8,02 \\
4 & Panen & 12,96 & 9,79 & 12,96 & 9,79 \\
5 & Pasca Panen & 13,66 & 10,39 & 13,66 & 10,39 \\
\hline & Jumlah & 63,00 & 47,82 & 63,00 & 47,82 \\
\hline & Rata-rata & 12,60 & 9,56 & 12,60 & 9,56 \\
\hline
\end{tabular}

Sumber : Data primer diolah, 2016

Dari tabel V-3 diatas dapat dilihat bahwa rata-rata penggunan tenaga kerja pada usahatani kakao berdasarkan jenis kegiatan di daerah penelitian per usahatani 12,60 HKP, sedangkan per hektar yaitu 9,56 HKP. Secara rinci penggunan tenaga kerja berdasarkan jenis kegiatan yang tertinggi adalah kegiatan pemupukan sebesar 16,40 HKP per usahatani dan 12,43 HKP per hektar, sedangkan yang terendah adalah pada kegiatan penanaman sebesar 9,53 HKP per usahatani dan 7,19 HKP per hektar. Penggunaan tenaga kerja yang digunakan hanya dari dalam keluarga saja, sedangkan yang luar keluarga tidak dibutuhkan. Hal ini disebabkan karena kegiatan usahatani kakao ini tidak membutuhkan tenaga kerja yang banyak dan untuk mengurangi biaya produksi.

Tabel V-4. Rata-rata Penggunaan Biaya Tetap pada Usahatani Kakao di Kecamatan Karang Baru, 2016.

\begin{tabular}{|l|l|r|r|}
\hline \multirow{2}{*}{ No } & \multicolumn{1}{|c|}{ Desa Sampel } & \multicolumn{2}{|c|}{ Biaya Tetap (Rp) } \\
\cline { 3 - 4 } & & Per UT & \multicolumn{1}{c|}{ Per Ha } \\
\hline 1 & Dalam & 335.877 & 230.916 \\
2 & Suka Jadi Paya Bujok & 327.064 & 277.509 \\
3 & Paya Awe & 360.875 & 267.315 \\
\hline & Rata-rata & 341.272 & 258.580 \\
\hline
\end{tabular}

Sumber : Data primer diolah, 2016

Tabel V-4 diatas dapat dilihat bahwa rata-rata penggunaan biaya tetap usahatani kakao di Kecamatan Karang Baru yaitu Rp 341.272 per usahatani dan Rp 258.580 per hektar. Penggunaan biaya tetap terbesar terdapat di

\section{Penggunaan Biaya Produksi}

Biaya produksi merupakan semua pengeluaran yang dilakukan oleh perusahaan untuk memperoleh faktor-faktor produksi dan bahan- bahan mentah yang akan digunakan untuk menciptakan barang-barang yang diproduksi pada perusahaan tersebut. Biaya produksi dalam penelitian ini terdiri dari biaya tetap dan biaya variabel. Penggunaan biaya tetap pada penelitian ini meliputi sewa lahan dan penyusutan alat. Sedangkan pada penggunaan biaya variabel meliputi : biaya bibit, biaya pupuk, dan biaya tenaga kerja. Untuk lebih jelas tentang besarnya biaya produksi dapat dilihat pada tabel berikut ini :
Desa Paya Awe yaitu Rp. 360.875 per usahatani dan Rp. 267.315 per hektar, sedangkan biaya tetap terkecil terdapat di Desa Suka Jadi Paya Bujok sebesar Rp. 327.064 per usahatani dan Rp. 277.509 per 
hektar. Penggunaan biaya tetap per usahatani lebih besar dibandingkan dengan per hektar hal ini disebabkan luas lahan usahatani kakao di Kecamatan Karang Baru rata- rata lebih dari satu hektar, sehingga biaya yang dikeluarkan lebih besar.

Penggunaan biaya variabel yang terdiri dari biaya pembelian bibit, pupuk dan tenaga kerja usahatani kakao dapat dilihat pada tabel berikut.

Tabel V-5. Rata-rata Penggunaan Biaya Variabel pada Usahatani Kakao di Kecamatan Karang Baru, 2016.

\begin{tabular}{|c|l|r|r|}
\hline \multirow{2}{*}{ No } & \multicolumn{2}{|c|}{ Desa Sampel } & \multicolumn{2}{|c|}{ Biaya Variabel (Rp) } \\
\cline { 3 - 4 } & & Per UT & Per Ha \\
\hline 1 & Dalam & 296.000 & 203.500 \\
2 & Suka Jadi Paya Bujok & 239.839 & 203.500 \\
3 & Paya Awe & 274.725 & 203.500 \\
\hline & Rata-rata & 270.188 & 203.500 \\
\hline
\end{tabular}

Sumber : Data primer diolah, 2016

Dari tabel V-5 diatas dapat dilihat bahwa jumlah penggunaan biaya variabel usahatani kakao di Kecamatan Karang Baru sebesar Rp 270.188 per usahatani dan Rp 203.500 per hektar. Penggunaan biaya variabel terbesar terdapat di Desa Dalam sebesar Rp. 296.000 per usahatani dan Rp. 203.500 per

hektar, sedangkan biaya variabel terkecil terdapat di Desa Suka Jadi Paya Bujok sebesar Rp. 239.839 per usahatani dan Rp. 203.500 per hektar.

Untuk mengetahui besarnya biaya produksi di Kecamatan Karang Baru dapat dilihat pada tabel berikut:

Tabel V-6. Rata-rata Penggunaan Biaya Produksi pada Usahatani Kakao di Kecamatan Karang Baru, 2016.

\begin{tabular}{|l|l|r|r|}
\hline \multirow{2}{*}{ No } & \multicolumn{1}{|c|}{ Desa Sampel } & \multicolumn{2}{|c|}{ Biaya Produksi (Rp) } \\
\cline { 3 - 4 } & & Per UT & Per Ha \\
\hline 1 & Dalam & 631.877 & 434.416 \\
2 & Suka Jadi Paya Bujok & 566.904 & 481.009 \\
3 & Paya Awe & 635.600 & 470.815 \\
\hline & Rata-rata & 611.460 & 462.080 \\
\hline
\end{tabular}

Sumber : Data primer diolah, 2016

Dari tabel V-6 diatas dapat dilihat bahwa jumlah penggunaan biaya produksi usahatani kakao di Kecamatan Karang Baru sebesar Rp 611.460 per usahatani dan $\mathrm{Rp}$ 462.080 per hektar. Penggunaan biaya produksi terbesar terdapat di Desa Paya Awe yaitu Rp. 635.600 per usahatani dan Rp. 470.815 per hektar, sedangkan biaya produksi terkecil terdapat di Desa Suka Jadi Paya Bujok yaitu Rp. 566.904 per usahatani dan Rp. 481.009 per hektar.

\section{Produksi dan Nilai Produksi}

Produksi adalah hasil dari jasa akibat penggunaan ataupun pemanfaatan faktorfaktor produksi. Selain dipengaruhi oleh kualitas faktor-faktor produksi, produksi juga sangat dipengeruhi oleh tingkat kombinasi yang tepat antara faktor-faktor produksi yang dilakukan oleh petani. Produksi yang dihasilkan dapat diukur dalam bentuk fisik yaitu dalam biji kakao kering, sedangkan nilai produksi adalah penerimaan yang berasal dari hasil produksi setelah dikalikan dengan harga jual. Berdasarkan hasil penelitian harga jual kakao per kilogram berkisar Rp. 25.000 - Rp. $28.000,-$. Untuk lebih jelas besarnya produksi dan nilai produksi dapat dilihat pada tabel.

Tabel V-7. Rata-rata Produksi dan Nilai Produksi pada Usahatani Kakao di AGRISAMUDRA, Jurnal Penelitian Vol. 4 No.2 Julii - Desember 2017 
Kecamatan Karang Baru, 2016.

\begin{tabular}{|l|l|r|r|r|c|}
\hline \multirow{2}{*}{ No } & \multicolumn{2}{|c|}{ Desa Sampel } & \multicolumn{2}{|c|}{ Produksi (Kg) } & \multicolumn{2}{c|}{ Nilai Produksi (Rp) } \\
\cline { 3 - 6 } & & Per UT & Per Ha & \multicolumn{1}{l|}{ Per UT } & \multicolumn{1}{c|}{ Per Ha } \\
\hline 1 & Dalam & 1.600 & 1.100 & 42.850 .000 & 29.459 .375 \\
2 & Suka Jadi Paya Bujok & 1.296 & 1.100 & 33.471 .429 & 28.400 .000 \\
3 & Paya Awe & 1.485 & 1.100 & 39.325 .000 & 29.129 .630 \\
\hline & Rata-rata & 1.460 & 1.100 & 38.548 .810 & 28.996 .335 \\
\hline
\end{tabular}

Sumber : Data primer diolah, 2016

Dari tabel V-7 diatas terlihat bahwa jumlah produksi usahatani kakao di Kecamatan Karang Baru yaitu $1.460 \mathrm{~kg}$ per usahatani dan $1.100 \mathrm{~kg}$ per hektar sedangkan nilai produksi yaitu $\mathrm{Rp}$. 35.548.810 per usahatani dan Rp. 28.996.335 per hektar.

\section{Pendapatan}

Pendapatan yang dianalisis dalam penelitian ini adalah pendapatan bersih. Pendapatan bersih adalah besarnya total penerimaan petani dari hasil penjualan biji kakao dikurangi total biaya produksi yang dikeluarkan. Untuk pendapatan bersih atau keuntungan petani kakao di Kecamatan Karang Baru dapat dilihat dapat pada tabel V-8 berikut

Tabel V-8. Rata-rata Pendapatan Usahatani Kakao di Kecamatan Karang Baru, 2016.

\begin{tabular}{|l|l|r|r|}
\hline \multirow{2}{*}{ No } & \multicolumn{1}{|c|}{ Desa Sampel } & \multicolumn{2}{|c|}{ Pendapatan (Rp) } \\
\cline { 3 - 4 } & & Per UT & \multicolumn{1}{c|}{ Per Ha } \\
\hline 1 & Dalam & 42.218 .123 & 29.024 .959 \\
2 & Suka Jadi Paya Bujok & 32.904 .525 & 27.918 .991 \\
3 & Paya Awe & 38.689 .400 & 28.658 .815 \\
\hline & Rata-rata & 37.937 .349 & 28.534 .255 \\
\hline
\end{tabular}

Sumber : Data primer diolah, 2016

Tabel V-8 diatas dapat dilihat bahwa jumlah pendapatan usahatani petani kakao di Kecamatan Karang Baru yaitu Rp. 37.937.349 per usahatani dan Rp 28.534.255 per hektar. Pendapatan terbesar di Desa Dalam sebesar Rp. 42.218.123 per usahatani dan Rp. 29.024.959 per hektar sedangkan yang terkecil di Desa Suka Jadi Paya Bujok sebesar Rp. 32.904 .525 per

\section{Tingkat Keterampilan}

Variabel yang menentukan tingkat keterampilan petani dalam usahatani kakao yang dinilai dalam penelitian adalah penggunaan bibit, teknik penanaman, pemupukan, pemangkasan, pengendalian HPT, pemanenan, dan pasca panen. Untuk lebih jelasnya tingkat keterampilan petani dilihat pada tabel V-9 berikut : usahatani dan Rp. 27.918.991 per hektar.

Tabel V-9. Rata-rata Tingkat Keterampilan Usahatani Kakao di Kecamatan Karang Baru, 2016

\begin{tabular}{|l|l|c|}
\hline & \multicolumn{1}{|c|}{ Desa } & $\begin{array}{c}\text { Rata-rata Keterampilan Petani } \\
\text { (Skor) }\end{array}$ \\
\hline 1 & Dalam & 2,6 \\
2 & Suka Jadi Paya Bujok & 2,6 \\
3 & Paya Awe & 2,5 \\
\hline & Rata-rata & 2,6 \\
\hline
\end{tabular}

Sumber : Data primer diolah, 2016

Tabel V-9 diatas menunjukkan bahwa rata-rata tingkat keterampilan usahatani petani kakao di Kecamatan Karang
Baru sebesar 2,6 skor. Secara rinci jumlah tingkat keterampilan di Desa Dalam dengan skor 2,6 skor, di Desa Suka Jadi Paya Bujok 
dengan skor 2,6 dan di Desa Paya Awe dengan skor 2,5. Artinya petani kakao dalam melakukan sistem penanaman sesuai anjuran.

\section{Pengaruh Biaya Produksi, Pengalaman, dan Keterampilan Terhadap Pendapatan Usahatani Kakao}

Analisis pengaruh biaya produksi, pengalaman, dan keterampilan terhadap pendapatan usahatani kakao di Kecamatan Karang Baru sedangkan faktor-faktor lain dianggap tetap. Hasil analisis diperoleh Persamaan Regresi Linear Berganda sebagai berikut :

$\mathrm{Y}=5,01-0,45 \mathrm{X}_{1}+0,06 \mathrm{X}_{2}+0,10 \mathrm{X}_{3}$.

Dari persamaan di atas dapat disimpulkan bahwa:

1. Jika $X_{2}$ dan $X_{3}$ dianggap tetap maka penambahan biaya produksi usahatani kakao sebesar Rp. 1.000.000 maka pendapatan petani usahatani kakao berkurang sebesar Rp 500.000. Hal ini terjadi karena semakin naik biaya produksi usahatani, maka pendapatan petani kakao dalam berusahatani semakin menurun.

2. Jika $X_{1}$ dan $X_{3}$ dianggap tetap maka penambahan pengalaman petani kakao 1 tahun maka pendapatan usahatani Uji F

Hasil pengujian secara serempak diperoleh Fhitung $=11,58>\mathrm{F}_{\text {tabel }}=2,90$ pada tingkat kepercayaan 95\% (Alpha= $0,05)$ dan juga $F_{\text {hitung }}=11,58>$ Ftabel $=$ 4,46 pada tingkat kepercayaan $99 \%$ (Alpha $=0,01)$, dapat diambil kesimpulan bahwa secara serempak biaya produksi,

\section{Uji t}

Hasil pengujian secara parsial pada variabel biaya produksi (X1) tingkat kepercayaan 95\% (Alpha $=0,05)$ dapat dilihat bahwa $\mathrm{t}_{1}$ cari $=-0,04<\mathrm{t}$ tabel $=1,695 \mathrm{dan}$ $\mathrm{t}$ tabel $=2,445$ pada tingkat kepercayaan $99 \%$ $($ Alpha $=0,01)$, ini berarti biaya produksi tidak berpengaruh terhadap pendapatan petani usahatani kakao di Kecamatan Karang Baru.

Hasil pengujian secara parsial pada variabel pengalaman $\left(\mathrm{X}_{2}\right)$ tingkat kepercayaan 95\% (Alpha $=0,05)$ dapat dilihat bahwa $\mathrm{t}_{2}$ cari $=0,10<\mathrm{t}$ tabel $=1,695$ dan $\mathrm{t}$ tabel $=2,445$ pada tingkat kepercayaan 99\% (Alpha $=0,01$ ), ini berarti tingkat pengalaman kakao bertambah sebesar Rp. 60.000. Hal ini terjadi karena semakin bertambah pengalaman petani usahatani kakao, maka pendapatan petani dalam berusahatani semakin bertambah.

3. Jika $X_{1}$ dan $X_{2}$ dianggap tetap maka penambahan keterampilan petani kakao 1 skor maka pendapatan usahatani kakao berkurang sebesar Rp. 110.000 . Semakin bertambah keterampilan

petani usahatani kakao, maka pendapatan petani dalam berusahatani kakao semakin bertambah dikarenakan bertambahnya keterampilan maka dapat meningkatkan hasil produksi.

Koefisien Determinasi $\left(\mathbf{R}^{2}\right)$

Hasil analisis koefisien determinasi $\left(\mathrm{R}^{2}\right)$ dihasilkan nilai $\mathrm{R}^{2}=0,53$ atau $53 \%$. Ini berarti pendapatan petani dalam berusahatani kakao (Y) dipengaruhi oleh biaya produksi, pengalaman, dan keterampilan sebesar $53 \%$ dan sisanya sebesar $47 \%$ lagi dipengaruhi oleh faktorfaktor lain diluar variabel penelitian ini seperti luas lahan, umur, dan pendidikan petani.

pengalaman, dan keterampilan memberi pengaruh yang sangat nyata terhadap pendapatan petani dalam berusahatani kakao. Hal ini disebabkan bahwa semakin bertambah biaya produksi, pengalaman, dan keterampilan maka tingkat pendapatan petani kakao di Kecamatan Karang Baru bertambah.

tidak berpengaruh terhadap pendapatan petani usahatani kakao di Kecamatan Karang Baru.

Hasil pengujian secara parsial pada variabel keterampilan (X3) tingkat kepercayaan $95 \%($ Alpha $=0,05)$ dapat dilihat bahwa $\mathrm{t} 3$ cari $=0,03<\mathrm{t}$ tabel $=1,695$ dan $\mathrm{t}$ tabel $=2,445$ pada tingkat kepercayaan 99\% (Alpha $=0,01)$, ini berarti tingkat keterampilan tidak berpengaruh terhadap pendapatan petani usahatani kakao di Kecamatan Karang Baru.

KESIMPULAN DAN SARAN

Kesimpulan 
1. Hasil analisis regresi linear berganda diperoleh persamaan yaitu sebagai berikut: $Y=5,01$ $0,45 \mathrm{X}_{1}+0,06 \mathrm{X}_{2}+0,10 \mathrm{X}_{3}$.

2. Dari koefisien determinasi menunjukkan bahwa nilai $\mathrm{R}^{2}=$ 0,53 atau $53 \%$.

3. Hasil pengujian secara serempak diperoleh variabel tingkat biaya produksi, pengalaman, dan keterampilan memberikan pengaruh yang sangat nyata terhadap pendapatan petani dalam berusahatani kakao.

4. Hasil pengujian secara parsial pada variabel biaya produksi (X1) pengalaman $\left(\mathrm{X}_{2}\right)$ dan variabel keterampilan (X3) tidak berpengaruh nyata terhadap pendapatan usahatani kakao.

\section{Saran}

Berdasarkan data yang telah dianalisis dan hasil pembahasan, serta kesimpulan maka dapat disarankan sebagai berikut :

1. Diharapkan adanya program dari pemerintah dalam mengembangkan produk pengolahan industri yang berbahan baku dari kakao, agar hasil produksi dapat berkembang menjadi produk berdaya jual tinggi.

2. Diharapkan para petani kakao lebih efesien dalam penggunaan biaya saprodi serta dapat meningkatkan keterampilannya dalam berusahatani kakao.

3. Diharapkan ada penelitian lanjutan tentang usahatani kakao yang meniliti dari sudut pandang lainnya dengan varibel-variabel penelitian yang berbeda.

\section{DAFTAR PUSTAKA}

Anonimous. 2014. Potensi Wilayah. Balai Penyuluhan Pertanian Kecamatan Karang Baru. Kabupaten Aceh Tamiang.

Anonimous. 2014. Laporan Produksi. Dinas Kehutanan dan Perkebunan Kabupaten Aceh Tamiang Kabupaten Aceh Tamiang,

Faturochman. 2004 Kependudukan dan Kebijakan.
Universitas Gadjah Mada. Pusat Studi

Dinamika Kependudukan dan Kebijakan. Yogyakarta.

Jhon Petrof. 2008. Pendapatan. Ht.www.bloc.spot.pendapatan.co.id.

Mubyarto. 1981. Metodologi Penelitian Ekonomi. Yayasan Agronomika. Yogyakarta. Nazir, Moh, 2005. Metode Penelitian. Cetakan ke V Ghalia Indonesia, Jakarta.

Rahim Abd. 2007. Ekonomika Pertanian (Pengantar Teori dan Kasus). Penebar Swadaya. Jakarta.

Rahmat, S, 2008. Tehnik Budidaya Kakao, http//www.budidaya kakao.com

Riadi, M. 2012. Biaya Produksi. www.kajianpustaka.com. diakses tanggal 11-02-2015.

Sedarmayanti, 2001. SDM Berkualitas Mengubah Visi Menjadi Realitas. PT. Gramedia Pustaka Utama. Jakarta.

Shinta, A. 2011. Ilmu Usahatani. Universitas Brawijaya Press (UB Press) Anggota IKAPI. Malang.

Simamora, H. 1995. Manajemen Sumber Daya Manusia. PT. Bumi Aksara. Jakarta.

Soemarjadi, 1991. Pengertian Keterampilan. www.pegertianketerampilan.guru keterampilan. Diakses 5-11-2015

Soekartawi. 2002. Analisis Usahatani. UI Press. Jakarta.

Sudjana, 2005. Teknik Analisa Regresi dan Korelasi. Tarsito. Bandung.

Sugiyono. 2008. Metode Pendidikan (Pendekatan Kuantitatif, Kualitatif dan $R \& D)$.

Penerbit Alfabeta. Bandung.

Sukirno, S. 2005. Pengantar Teori Mikroekonomi. Bima Grafika. Jakarta.

Sunanto, 2002. Kakao, Budidaya, Pengolahan Hasil dan Aspek Ekonominya, Kanisius, Yogyakarta.

Suratiyah, K. 2008. Ilmu Usahatani. Penebar Swadaya. Jakarta.

Su'ud, M.H. 2004. Pengantar Ilmu Pertanian. Yayasan Cendekia Membangun Citra. Jakarta 